\title{
Euclides da Cunha
}
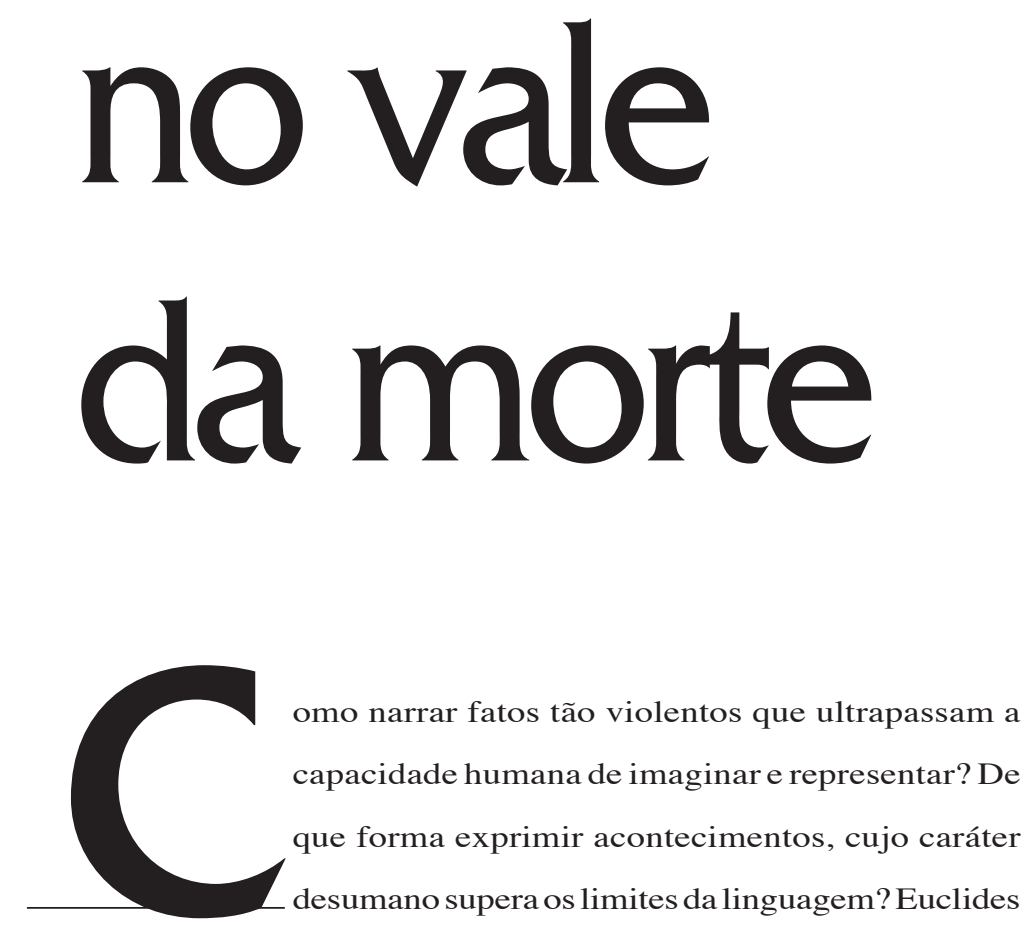

da Cunha se deparou com tais questões, ao escrever Os Sertões (Campanha de Canudos), em que acusou o Exército, a Igreja e o governo pelo extermínio da comunidade liderada por Antônio Conselheiro.

Redigido com o propósito de denunciar o crime cometido em Canudos, seu livro traz um curioso paradoxo, já que deixa de relatar aquilo que forma a base de sua acusação contra as forças

\section{ROBERTO VENTURA}

é professor de Teoria Literária e Literatura Comparada na USP e autor de, entre outros, Estilo Tropical: História Cultural e Polêmicas Literárias no Brasil (Companhia das Letras). armadas: o massacre dos prisioneiros e a destruição da cidade. Tais eventos de crueldade extrema são antes sugeridos do que propriamente narrados, já que não haveria linguagem capaz de exprimir tamanho horror: "Forremo-nos à tarefa de descrever os seus últimos momentos. Nem poderíamos fazê-lo. Esta página, imaginamo-la sempre profundamente emocionante e trágica; mas 


\section{os sertões âtós}

cerramo-la vacilante e sem brilhos" (1).

De modo a exprimir aquilo que é inexprimível, ou representar o irrepresentável, Euclides oscila entre as imagens antitéticas de paraíso e inferno, de salvação e perdição, pelas quais procura captar o caráter tenso e contraditório da história e da natureza. Concebeu a história como drama trágico e empregou metáforas cênicas e formas suspensivas de narração, que se ligam aos recursos de encenação do teatro grego. A epopéia gloriosa da República brasileira, pela qual combatera na juventude, como cadete da Escola Militar e articulista político de A Província de S. Paulo, adquiriu sentido de tragédia na brutal intervenção militar que testemunhou no sertão da Bahia.

Publicado em 1902, cinco anos após o término do conflito, Os Sertões resultou de sua cobertura da Guerra de Canudos como correspondente de $O$ Estado de $S$.

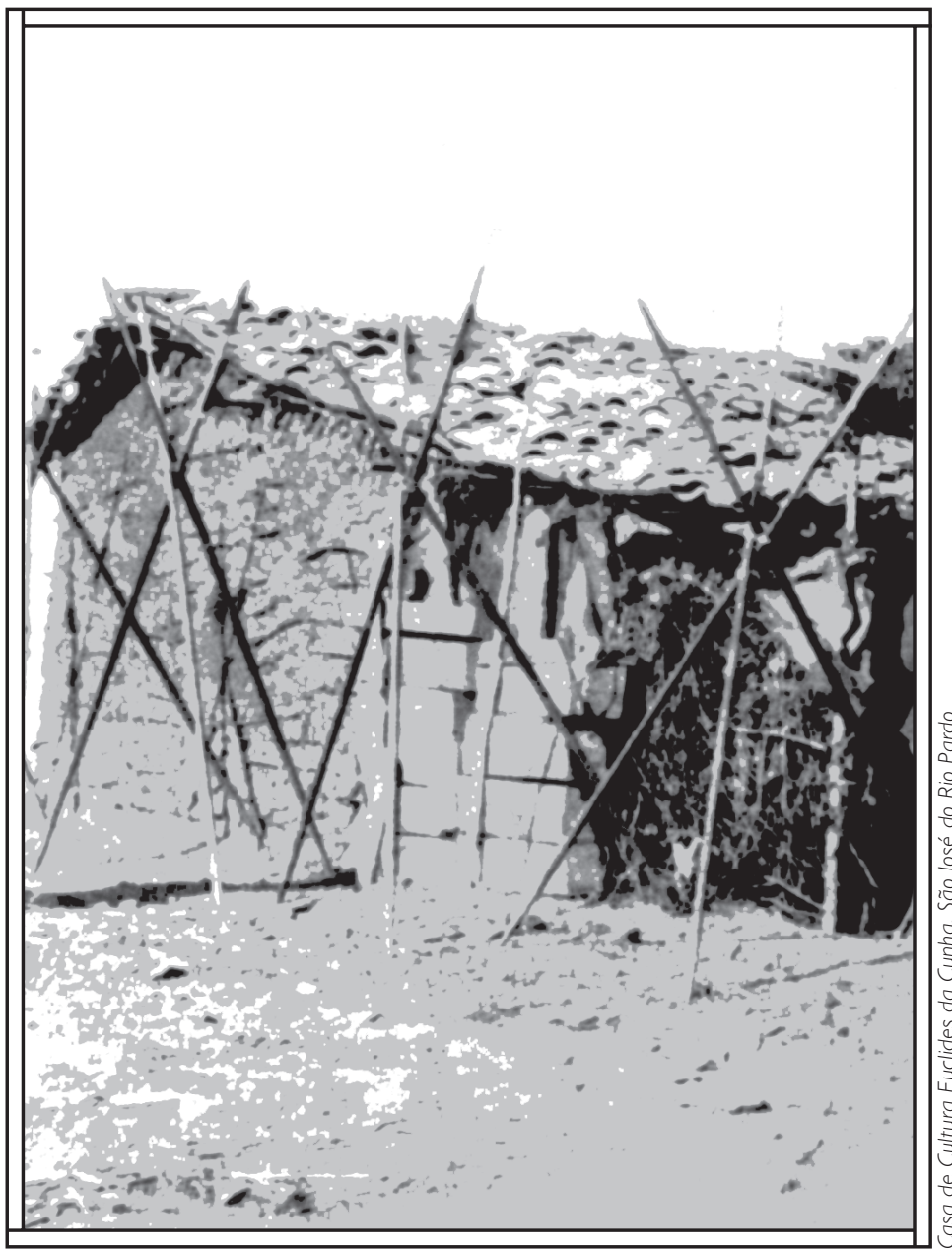

Paulo. Acompanhou, de agosto a outubro de 1897 , a 4ª e última expedição, formada por oito mil soldados, equipados com moderno armamento, cuja retaguarda foi organizada pelo próprio ministro da Guerra, marechal Carlos Machado de Bittencourt. Fez, no livro, a autocrítica do patriotismo exaltado de suas reportagens e reconheceu a omissão de sua cobertura jornalística, ao denunciar a matança dos presos, sobre a qual antes se calara.

Relatou, na última reportagem para o

jornal, o sangrento combate de $1^{\circ} \stackrel{\circ}{d e}$ outubro, dois dias antes de sair de Canudos, cuja ferocidade, com grandes perdas de ambos os lados, o deixou em estado de choque: "Felizes os que não presenciaram nunca um cenário igual...”. As pilhas de cadáveres e os inúmeros feridos que gemiam amontoados no leito seco do rio the lembraram o vale do Inferno, que Dante Alighieri (1265-1321) percorreu n'A Divina Comédia:

Euclides da Cunha, Os Sertõe (Campanha de Canudos (1902), ed. de Walnice Nogueira Galvão, São Paulo, Átca, 1998, p. 497 
“compreendi o gênio sombrio e prodigioso de Dante. Porque há uma coisa que só ele soube definir e que eu vi naquela sanga estreitíssima, abafada e ardente, mais lúgubre que o mais lúgubre vale do Inferno: a blasfêmia orvalhada de lágrimas, rugindo nas bocas simultaneamente com os gemidos da dor e os soluços extremos da morte".

Tal visão infernal deixou profundas marcas no ex-militante republicano, cujas crenças políticas foram abaladas: "sentia um desapontamento doloroso e acreditei haver deixado muitos ideais, perdidos, naquela sanga maldita, compartindo o mesmo destino dos que agonizavam manchados de poeira e sangue..." (2).

Procurou superar, em Os Sertões, seu remorso e perplexidade com o desfecho brutal da campanha, para o qual contribuiu, ainda que de modo involuntário, com artigos que se encerravam com os brados patrióticos de "viva a República” ou “a República é imortal". Fez coro, como quase toda a imprensa, com aqueles que viam na rebelião um grave perigo para a ordem republicana e silenciou nas reportagens sobre as atrocidades cometidas pelas tropas, que degolaram ou estriparam, de forma impiedosa, os prisioneiros que se haviam rendido com garantias de vida ao general Artur Oscar de Andrade Guimarães, comandante da $4^{\underline{a}}$ Expedição (3).

A visão do horror, que Euclides encarou no vale da morte em Canudos, às margens do Rio Vaza-Barris, no nordeste da Bahia, foi também exposta pelo polonês Joseph Conrad, ao tratar da colonização predatória do Congo belga na novela Heart of Darkness (Coração das Trevas) (1902), pelo italiano Primo Levi nas memórias de Se Questo è un Uomo (É Isto um Homem?) (1947), em que conta sua terrível experiência como prisioneiro em um campo de concentração alemão, ou ainda pelo cineasta Francis Ford Coppola, que adaptou, de forma livre, a ficção de Conrad em Apocalypse Now (1979), filme sobre a guerra do Vietnã.

Coração das Trevas saiu em volume no mesmo ano da publicação de Os Sertões. Na novela de Conrad, o capitão Marlow relata a viagem pelo Rio Congo em busca do agente Kurtz, negociante de marfim, que criou em torno de si um culto baseado em sacrifícios humanos, com a participação das tribos locais. A trajetória de Marlow rumo ao interior da África, com o objetivo de tirar Kurtz de seu posto comercial, torna-se um mergulho no desconhecido não só geográfico e cultural, mas sobretudo existencial e metafísico, pois o coloca frente a realidades que degradam a condição humana. Em um dos postos da companhia, homens negros acorrentados trabalhavam até à morte, como se fossem sombras, na construção de uma ferrovia. A viagem do narrador ao “coração das trevas" se converte em rito de iniciação ao mal absoluto, equivalente, em suas próprias palavras, à descida ao "sombrio círculo de algum Inferno”.

Deitado na escuridão à espera da morte no barco que o deveria levar de volta ao litoral, Kurtz exclama antes de expirar: "O horror! O horror!’. Esta exclamação fúnebre se torna, para Marlow, a síntese de uma crença ampla o suficiente para abarcar todo o universo: "Ele resumira-fizera um juízo. 'O horror!'”. O grito de Kurtz trazia a nota vibrante da revolta ou a face aterrorizante de uma verdade apenas entrevista, pela qual manifestava sua aversão à vida e à história. Com uma ironia tão cínica quanto piedosa, Marlow encerra seu relato com a terna visita, já de volta a Londres, à noiva de Kurtz, para lhe devolver um retrato e suas cartas. À pergunta da moça, que queria saber ansiosa quais foram as últimas palavras de seu pretendente, o capitão prefere mentir e responde que fora o nome dela, pois a verdade era demasiado sombria para ser dita... (4).

Já Primo Levi recria, em É Isto um Homem?, sua vivência como prisioneiro no campo de Auschwitz, na Polônia, para onde foi deportado em 1944. Sentiu estar entrando no inferno, quando chegou ao campo depois de uma longa viagem de quatro dias de trem, sem nada para beber, e teve que ficar parado de pé, em uma sala grande e vazia, junto com outros prisioneiros, diante de uma torneira gotejante, cuja água não era potável: “Como é possível 
pensar? Não é mais possível; é como se estivéssemos mortos".

O soldado alemão, que perguntava, no caminhão em direção ao campo, se tinham relógios ou dinheiro para lhe dar, recordava, de forma sinistra, o barqueiro Caronte d'A Divina Comédia de Dante, que conduzia, através do Rio Aqueronte, as almas condenadas ao Inferno e lhes lançava a maldição: “Ai de vós, almas danadas!/ Nunca mais ireis ver de novo o céu” (5). Em "O Canto de Ulisses", uma das mais belas passagens de suas memórias, Levi recita para outro prisioneiro trechos do $26^{\circ}$ canto do "Inferno", primeira parte do poema de Dante, em que Ulisses conta como morreu no naufrágio de sua nau, quando explorava o oceano Atlântico.

Logo na entrada de Auschwitz, em cima do portão, avistava-se um bem iluminado letreiro, cujas palavras maliciosas iriam atormentar Levi em pesadelos pelo resto da vida: "Arbeit macht frei" ("O trabalho liberta"). Antes de ingressar no campo, os prisioneiros eram obrigados a deixar para trás seus sapatos, objetos e roupas, tinham os cabelos e as barbas raspados, passavam pelas duchas de desinfecção e vestiam uniformes listrados. Reduzidos a fantasmas, tudo lhes era arrancado, até o próprio nome, substituído por um número tatuado no braço esquerdo. O escritor mostra não ter palavras para dar conta de tal negação da condição humana:

"Pela primeira vez, então, nos damos conta de que a nossa língua não tem palavras para expressar esta ofensa, a aniquilação de um homem. Num instante, por intuição quase profética, a realidade nos foi revelada: chegamos ao fundo. Mais para baixo não é possível. Condição humana mais miserável não existe, não dá para imaginar" (6).

Depois de passar pela funesta experiência de viver e de sobreviver ao holocausto, Levi sentiu a necessidade de dar seu testemunho de uma realidade indizível por sua radical desumanidade. Com o término da Segunda Guerra Mundial, em 1945, sua libertação lhe trouxe a exigência de uma outra liberação, agora interior, manifestada como um "impulso imediato e violento" de contar aos outros sua traumática passagem pelo campo, em que eram exterminadas não só vidas, mas a própria condição humana dos sobreviventes.

Além de É Isto um Homem?, Levi escreveu La Tregua (A Trégua) (1958), sobre a viagem de volta para sua casa em Turim, na Itália, que o fez errar por vários países. Saído do campo, deparou-se com a mesma maldade, miséria e anti-semitismo que a trégua não extinguira - "guerra é sempre", diz-lhe um grego companheiro de viagem (7). Seu suicídio em 1987, aos 68 anos, mortificado pelo sofrimento da mãe doente de câncer, que lhe lembrava as atrocidades de Auschwitz, indica que foram apenas parciais ou transitórios a liberação ou o consolo trazidos pela escrita.

\section{DO INFERNO AO PARÁISO}

Euclides da Cunha passou quatro anos após o término do conflito de Canudos preenchendo centenas de folhas de papel com sua letra minúscula, para ordenar o caos e superar o vazio, trazidos sob o impacto daquela "região assustadora", de onde voltou deprimido e doente. Seguia revendo na mente as "Muitas cenas do drama comovente/ De guerra despiedada e aterradora", conforme escreveu, já de volta a Salvador, no poema "Página Vazia", cujos versos eram, segundo ele, "tão mal feitos e tão tristes" (8).

A "região assustadora", cujo horror a linguagem mal pode exprimir, traz ecos da "selva selvagem", com que Dante se depara na abertura da Divina Comédia:

“Ah! Descrever não posso esta espessura, esta selva selvagem, densa e forte, que em relembrá-la a mente se tortura!

Ela era amarga, quase como a morte!" (9).

"A meio caminho desta vida", Dante se perde da "via veraz" e erra por uma floresta
5 Dante Alighieri, A Divina Comédia (1307-21), trad. de Cristiano Martins, Belo Horizonte, São Paulo, Itatiaia/ Edusp, 1976, p. 100

6 Primo Levi, Se Questo è un Uomo (1947), Torino, Einaudi 1976 |É Isto um Homem?, trad de Luigi del Re, Rio de Janeiro Rocco, 1997, pp. 24-5)

7 Idem, La Tregua (1958) Torino, Einaudi, 1989 |A Tré gua, trad. de Marco Lucchesi, São Paulo, Companhia das Le tras, 1997, p. 76).

8 E. da Cunha, "Página Vazia" (1897), in Obra Completa, Rio de Janeiro, Nova Aguilar 1995 , v. 1, p. 726

9 D. Alighieri, op. cit., p. 85. 
escura, até encontrar o vulto de outro poeta, Virgílio, que o guia pelos círculos do Inferno e pelos terraços do Purgatório. $\mathrm{Pu}$ rificado nesta travessia, sobe às esferas luminosas do Paraíso, acompanhado de sua amada Beatriz.

A visão do inferno, que Euclides evocou nas reportagens a partir da referência a Dante, se faz presente em Os Sertões junto com seu reverso, a busca do paraíso. Citou os poemas populares sobre a Guerra de Canudos e interpretou as profecias do fim do mundo que atribuiu a Antônio Conselheiro, de modo a incorporar a seu relato a visão de mundo dos sertanejos. Recolheu tais fontes orais a partir dos papéis e cadernos que foram encontrados pelos soldados e oficiais nas ruínas da comunidade.

General

Os sermões reunidos por Antônio Con-

Barbosa e seu estado maior,

Canudos profeta milenarista retratado em $\mathrm{Os} \mathrm{Ser}$ tões. Revelam um líder religioso, que seguia um catolicismo tradicional, baseado no modelo da vida piedosa e penitente, tida como forma de se atingir a salvação.

O Conselheiro atuou como pregador leigo e construtor de capelas, igrejas e cemitérios no interior da Bahia e Sergipe, seguindo a tradição dos beatos e eremitas, que dedicavam a vida à religião e levavam a fé às populações do interior. Foi porém proibido em 1882 de pronunciar sermões pelo arcebispo da Bahia, que temia sua crescente influência. Seus conflitos com as autoridades se agravaram com a proclamação da República, à qual se opunha, criticando a cobrança de novos impostos, a secularização dos cemitérios e a criação do casamento civil e do registro civil de mortes e nascimentos. Tinha uma crença mística na monarquia, forma política tida como eterna e abençoada por Deus. Acreditava que a restauração do trono e o retor-

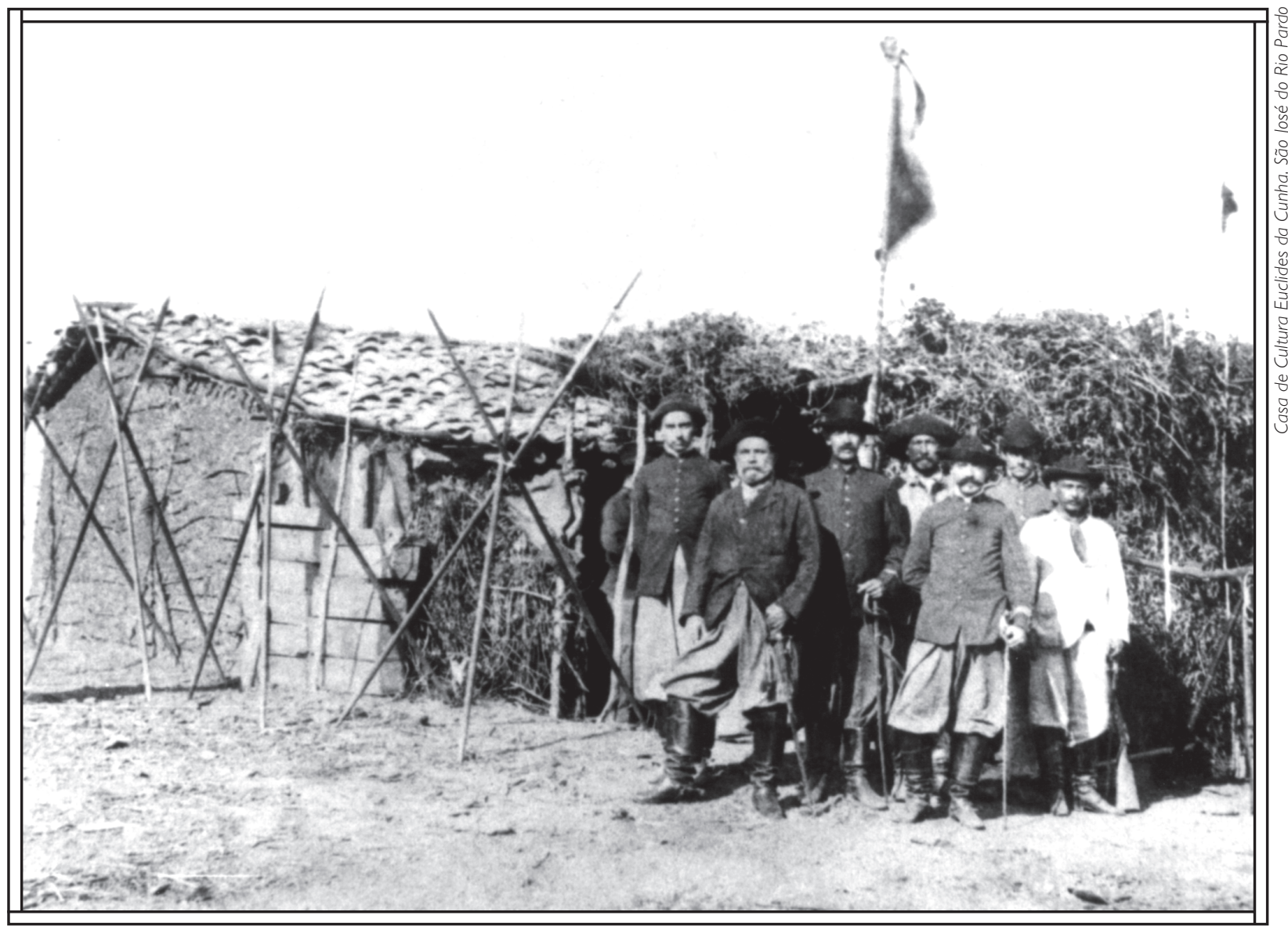


no da família real eram fatos tão inevitáveis quanto o raiar do sol no início de cada novo dia (10).

Para Euclides, a preocupação dominante dos habitantes do sertão era a "felicidade suprema da volta para os céus", aspiração espiritual que permitiria superar as limitações de uma vida miserável. Considerado pelos seguidores do Conselheiro como paraíso ou terra de promissão, Canudos se converte, em Os Sertões, no seu oposto - o inferno. O viajante precisaria atravessar "estradas fascinadoramente traiçoeiras que levam ao Inferno" até chegar ao povoado, “imunda ante-sala do Paraíso", "pobre peristilo dos céus".

"Barbaramente estéreis" e "maravilhosamente exuberantes”, os sertões formam, para Euclides, uma categoria geográfica própria, paradoxal e única, capaz de se transfigurar em "mutações fantásticas" e de alternar, segundo um "ritmo maldito", entre a aridez dos desertos e a abundância dos vales férteis: “A natureza compraz-se em um jogo de antíteses". A região é marcada pelo conflito permanente entre dias quentes e noites frias, ou entre períodos infernais de seca e momentos edênicos trazidos pelas chuvas, em que a caatinga, até então árida e desértica, transforma-se em paraíso: "É uma mutação de apoteose" (11).

Euclides capta duas visões fantásticas sugeridas pela secura extrema e pela topografia peculiar do vale do Vaza-Barris: a ilusão do mar e a miragem do céu. Ambas as visões se ligam à espera de salvação anunciada tanto por sinais da natureza quanto pelos presságios apocalípticos, que considerou, talvez com engano, serem da autoria do Conselheiro.

Do alto do morro da Favela, onde se instalaram os canhões que bombardeavam Canudos, o narrador observa as longínquas montanhas que lhe parecem suspensas no ar, e tem a impressão de contemplar o mar devido às diferenças de temperatura entre as camadas do solo. $\mathrm{O}$ "ondular estonteador”, ou o "estranho palpitar das vagas longínquas”, que avista ao norte da Serra da Canabrava, criava a "ilusão maravilhosa de um seio de mar”. A miragem do mar o acompanhou em seu trajeto pela caatinga, dando-lhe a "impressão persistente de calcar o fundo recém-sublevado de um mar extinto", que teria deixado o solo marcado pela "agitação das ondas e voragens". Tal tumulto na paisagem se torna análogo, na construção de Os Sertões, ao causado na história e na política pela rebelião dos conselheiristas

No intuito de combinar literatura, história e ciência, Euclides adotou idéias controversas do geólogo francês Emmanuel Liais sobre a existência pré-histórica de mar no sertão da Bahia, que se tornaria prenúncio das profecias atribuídas ao Conselheiro de que o sertão iria virar "praia", expressão que designa as zonas úmidas entre o litoral e o semi-árido, tornando-se terra de promissão, capaz de abrir as portas do paraíso: "Em 1896 hade rebanhos mil correr da praia para o certão; então o certão virará praia e a praia virará certão” (12). Tais presságios foram retomados por Glauber Rocha, no filme Deus e o Diabo na Terra do Sol (1963), como estribilho revolucionário, que celebra a reforma agrária e a redenção política, simbolizadas pelas ondas do vasto mar, para onde corre o vaqueiro Manuel na apoteótica cena final.

A ilusão de céu, outro efeito visual criado pela geografia do sertão, converte-se em anúncio de salvação n'Os Sertões. Visto de cima, Canudos dava a impressão de um "platô elevadíssimo" ou de uma "planície ondulante e grande", o que fazia os "matutos crendeiros" acreditar que "ali era o céu...": "a sua topografia interessante modelava-o ante a imaginação daquelas gentes simples como o primeiro degrau, amplíssimo e alto, para os céus..." (13).

Amparado na ilusão do degrau para os céus, o Conselheiro prometeria, segundo Euclides, o paraíso em suas pregações. "Emissário das alturas" e "delegado dos céus", o profeta anunciaria "o reino de mil anos e suas delícias" como um "bufão arrebatado numa visão do Apocalipse". Abraçaria crenças milenaristas sobre a chegada de uma nova era de felicidade, que poria fim às desgraças trazidas pelas secas do sertão e pela opressão da República.
10 Antônio Vicente Mendes Maciel, "Sobre a República" 11897), in Ataliba Nogueira Antônio Conselheiro e Canu dos: Revisão Histórica, São Paulo, Nacional, 1978 pp. 176-7; Alexandre Otten, "So Deus é Grande": AMensagem Religiosa de Antônio Conseheiro, São Paulo, Loyola, 1990 , pp. 203-355

11 E. da Cunha, Os Sertões, op. cit., pp. 51, 65, 169.

12 ldem, ibidem, p. 149. Sobre as idéias geológicas em $\mathrm{O}$ Sertões, cf.: José Carlos Barreto de Santana, Ciência \& Arte: Euclides da Cunha e as Ciên cias Naturais, São Paulo, Hucitec, 2001, pp. 111 segs

13 E. da Cunha, Os Sertões, op. cit., pp. 34, 39, 158 
O capuchinho italiano, frei João Evangelista do Monte Marciano, enviado em 1895 pela Igreja a Canudos com a missão fracassada de dispersar a comunidade, também julgou que seus participantes nutriam esperanças sobre a criação do reino dos céus na terra. Afirmou, no relatório citado por Euclides, que os "aliciadores da seita" procuravam persuadir o povo de que a cidade era o portal do paraíso, espalhando pelo sertão que "todo aquele que se quiser salvar precisa vir para os Canudos, porque nos outros lugares tudo está contaminado e perdido pela República: ali, porém, nem é preciso trabalhar; é a terra da promissão, onde corre um rio de leite e são de cuscuz de milho os barrancos" (14).

Frei Marciano retoma a representação do paraíso terrestre, anterior à queda de Adão e Eva, tal como descrito na Bíblia, no livro do Gênesis. De acordo com a versão bíblica da criação do mundo, Deus plantou um jardim das delícias em Éden, no Oriente, cortado por quatro rios, com toda espécie de árvores e frutos, onde colocou o primeiro homem, a primeira mulher e todos os animais. Com base na descrição do Gênesis, profetas, como Isaías e Daniel, previram o surgimento de um reino sem fim ou de um império eterno, com paz, direito e justiça, que restauraria o paraíso ao reunir todos os povos e nações sob a autoridade de um único rei. A partir dos profetas da Bíblia e de autores latinos, como Ovídio, Virgílio e Plínio, o Velho, escritores cristãos medievais abordaram o paraíso terrestre, tema depois retomado por pensadores e viajantes desde a renascença (15).

Para o historiador Jean Delumeau, o milenarismo enquanto expectativa de mil anos de felicidade terrestre se liga à nostalgia do paraíso perdido, proveniente do Gênesis bíblico, que se procura reencontrar pela criação do reino dos céus na terra: "O milenarismo, espera de um reino deste mundo, reino que seria uma espécie de paraíso terrestre reencontrado, está [...] estreitamente ligado à noção de uma idade de ouro desaparecida" (16). Tal esperança do paraíso terrestre adquiriu contornos laicos a partir do século XVIII, para dar corpo à ideologia do progresso e às utopias políticas modernas.

Como mostra Sérgio Buarque de Holanda, em Visão do Paraíso (1959), os primeiros viajantes e exploradores europeus da América projetaram a imagem do Éden sobre o novo continente, retomando as descrições do paraíso terrestre dos teólogos da Idade Média, que o concebiam não como um mundo inatingível, perdido no começo dos tempos, mas enquanto realidade acessível, ainda que em um sítio longínquo. Nessa projeção, o continente americano é visto como região de eterna primavera, com temperatura constante, o que repete as descrições medievais do paraíso. Enquanto no velho mundo a natureza avara, repartida em estações, só recompensava os previdentes, os diligentes e os pacientes, no mundo americano ela se entregaria de imediato ao homem, como dádiva de Deus, sem a dura necessidade de recorrer ao trabalho constante.

Tal visão do paraíso se encontra, por exemplo, no relato da primeira viagem de Colombo, na Historia de las Indias, de Bartolomé de Las Casas (1474-1566), no Tratado da Terra do Brasil (1573), de Gândavo, na Crônica da Companhia de Jesus (1663), de Simão de Vasconcelos (17). Faz-se presente ainda na História da América Portuguesa (1730), de Rocha Pitta, que Euclides considerava um escritor gongórico ou rebuscado, cujos exageros descritivos se deveriam ao aspecto majestoso da natureza brasileira.

\section{SOB 0 VIÉS DA IRONIA}

O historiador norte-americano Hayden White observou, em ensaio de 1987, que a diferença entre história e ficção reside mais no conteúdo do que propriamente na forma, enfatizando a proximidade da escrita da história com os modos literários de narrar. A história trata de acontecimentos reais, passíveis de comprovação por meio de documentos ou testemunhos, enquanto a ficção apresenta fatos imaginários ou inventados. 
Ambas são porém construções verbais, que ordenam e codificam os fatos de acordo com as formas de ficção ou as estruturas de enredo adotadas. Para White, o estilo historiográfico exprime uma "combinação particular de modos de elaboração de enredo, argumentação e implicação ideológica”, em que a argumentação supõe uma operação cognitiva e a construção do enredo uma percepção estética do passado (18).

Euclides retratou Antônio Conselheiro como personagem trágico, guiado por forças obscuras e ancestrais e por maldições hereditárias, que o teriam levado à insanidade e ao conflito com a ordem. Viu Canudos como desvio histórico capaz de ameaçar a "linha reta", que ele, Euclides, seguia desde a juventude, entendida como a fidelidade aos princípios éticos e políticos amparados na crença no progresso e na República. Freqüente em suas cartas aos amigos e familiares, a imagem da linha reta deu forma à retidão de caráter que procurou manter ao longo da vida e se ligava ao conceito linear e evolutivo de história, adotado por positivistas e evolucionistas, que acreditavam no aperfeiçoamento progressivo do homem e da sociedade (19).

Filho de um comerciante, nascido em 1830 em Quixeramobim, no interior do Ceará, Antônio Vicente Mendes Maciel, conhecido como o Peregrino ou o Conselheiro, iniciou sua peregrinação mística na década de 1870, depois de ter sido abandonado pela mulher, que fugira com um policial, e de ter os bens penhorados para o pagamento de uma dívida. Seus familiares participavam, desde a década de 1830 , de um sangrento combate contra um clã inimigo. Para Euclides, tal luta entre famílias teria criado uma "predisposição fisiológica" nos seus descendentes, que tornou hereditários os rancores e as vinganças, de modo semelhante aos personagens trágicos dos mitos gregos.

O crítico canadense Northrop Frye enfocou, em Anatomy of Criticism (Anatomia da Crítica) (1957), o personagem trágico como um líder situado entre o divino e o humano, que se move do heróico ao irônico, por ser muito grande se compara- do ao homem comum, mas que se mostra falho frente aos deuses ou ao destino: "O herói trágico situa-se tipicamente no topo da roda da fortuna, a meio caminho entre a sociedade humana, no solo, e algo maior, no céu". Limitado por uma ordem natural ou divina, o protagonista da tragédia é humilhado e acaba por entrar em agonia, muito distante da atitude heróica inicial.

Frye define a atitude irônica a partir do eíron, o homem que se censura. A ironia se afasta das formulações diretas ou óbvias em favor dos sentidos velados e sugeridos: "O termo ironia, portanto, indica uma técnica, de alguém parecer que é menos do que é, a qual, em literatura, se torna muito comumente uma técnica de dizer o mínimo e de significar o máximo possível". E conclui: "O escritor de ficção irônica, portanto, censura-se".

Ao contrário da tragédia, em que a catástrofe do herói se relaciona de forma plausível com seu caráter e ações, a ironia torna arbitrária a situação trágica, ao mostrar que a vítima é um bode expiatório, escolhido por acaso e que não merece o que lhe acontece: "o princípio fundamental da ironia trágica é que tudo de excepcional que aconteça com o herói devia estar causalmente descombinado com o seu caráter" (20). Surgindo da comédia e da ficção realista, a ironia se move em direção ao mito, fazendo surgir os contornos obscuros das cerimônias de sacrifício.

Euclides recorreu à ironia para mostrar como a Guerra de Canudos negou ou inverteu o mito glorioso da Revolução Francesa. Conhecera tal mito pelos relatos românticos de Victor Hugo, com o romance Quatrevingt-treize (Noventa e Três) (1874), sobre a guerra dos camponeses católicos da região da Vendéia, e de Jules Michelet, com a Histoire de la Révolution Française (História da Revolução Francesa) (187453). Ambos, Hugo e Michelet, transformaram o povo em herói coletivo, procedimento também adotado por Euclides ao enfocar o sertanejo em Os Sertões.

O escritor fez, em seu livro sobre Canudos, a autocrítica do tom patriótico de suas reportagens e se afastou da comparação
18 Hayden White, Metahistory the Historical Imagination in Nineteenth-century Europe (1973), Baltimore, London, Th Johns Hopkins Univ. Press 1985 pp. 27-9 |Meta-histó ria: Almaginação Histórica do Século XIX, trad. de José Laurênio de Melo, São Paulo Edusp, 1992 po 41-3|. Idem, "The Question of Narrative in Contemporary Historical Theor" in The Content of the Form: Narrative Discourse and Historical Representation Baltimore, London, The John Hopkins Univ. Press, 1987, pp. 27 e segs. Para uma aborda gem crítica da relação entre história e ficção em Hayden White e seus efeitos na repre sentação do holocausto, ct: Luiz Costa Lima, "O Revisionismo Histórico: uma Conseqüência Imprevista", in Mímesis: Desafio ao Pensamento, Rio de Janeiro, Civil zação Brasileira, 2000, pp. 238-47.

19 Euclides da Cunha emprega a imagem da linha reta nas car tas a Bueno Brandão (28/ abr./1896 eb/dez./18691 ao pai (22/set / 1903,25 ago./1904 e 14/fev. 1906), a Coelho Neto (22) nov./19031, ao cunhado Otaviano Vieira 15 /nov. 1908) e ao historiador Olivejra Lima (13/nov. / 1908). Cf. Walnice Nogueira Galvão Oswaldo Galotti (orgs.), Cor respondência de Euclides da Cunha, São Paulo, Edusp 1997, pp. 95 e segs.

20 Northrop Frye, Anatomy of Criticism: Four Essays (1957) Princeton, Princeton Univ. Press, 1973, pp. 40-1, 207 | Anato mia da Crítica: Quatro Ensaios, trad. de Péricles Eugênio da Silva Ramos, São Paulo, Cultrix, s.d., pp. 46-7, 204) 
entre a história brasileira e a Revolução Francesa, empregada nos artigos de março e julho de 1897, com o título de "A Nossa Vendéia”, redigidos antes de viajar à Bahia. Aproximara, nesses artigos, a guerra no sertão à rebelião em 1793 dos camponeses monarquistas e católicos da região da Vendéia contra a França revolucionária. Tal comparação mostrava sua certeza da vitória do governo, tão inabalável quanto a crença do Conselheiro na volta da monarquia: “Este paralelo será, porém, levado às últimas consequiências. A República sairá triunfante desta última prova" (21).

Descartou depois, em Os Sertões, a idéia de uma conspiração monárquica, apoiada por países estrangeiros, que havia justificado o massacre. Mostrava agora que a rebelião liderada pelo Conselheiro não apresentava o projeto político de derrubada da República. Tratava-se antes, para Euclides, de um movimento místico e religioso, fundado em expectativas milenaristas de criação do paraíso terrestre e em crenças sebastianistas sobre o retorno mágico do rei português d. Sebastião, desaparecido no século XVI, que deveria voltar, com suas tropas, para derrotar as forças do novo regime.

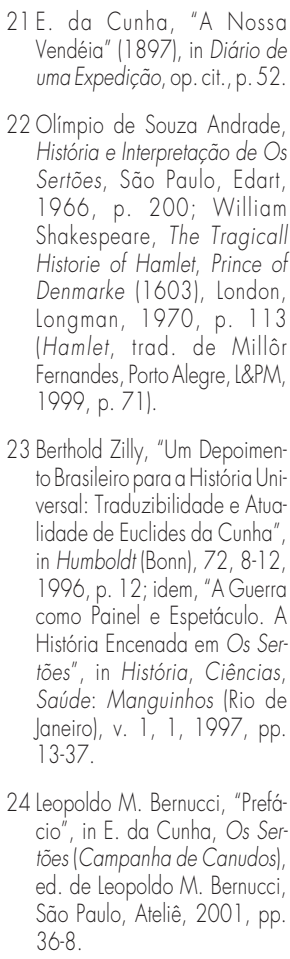

23 Berthold Zilly, "Um Depoimento Brasileiro para a História Universal: Traduzibilidade e Atualidade de Euclides da Cunha" in Humboldt (Bonn), 72, 8-12, 1996, p. 12; idem, "A Guerro como Painel e Espetáculo. A História Encenada em Os Sertões" in História Ciências, Saúde: Manguinhos (Rio de Janeiro), v. 1, 1, 1997, pp 13-37

24 Leopoldo M. Bernucci, "Prefá cio", in E. da Cunha, Os Ser tões (Campanha de Canudos). ed. de Leopoldo M. Bernucci, São Paulo, Ateliê, 2001, pp 36-8.

barracão de obras, de onde fiscalizava as obras da ponte, escreveu a indagação amarga e irônica do Hamlet de Shakespeare, surpreso com a alegria da mãe, a rainha Gertrude, após a misteriosa morte do marido: "What should a man do but be merry?" (“Que faria o homem, se não risse?”) (22).

Berthold Zilly, tradutor alemão de $O s$ Sertões, observou que o escritor recriou a guerra como tragédia, em que o não-herói, o sertanejo, revela-se como o único herói numa transfiguração quase milagrosa de apoteose: “A História é apresentada como trágica, repleta de infelicidades, infâmias e catástrofes, um imbricamento de progressos e retrocessos marcados por hecatombes" (23).

A linguagem dramática, freqüente no livro, articula-se ao discurso militar, em que são correntes termos como "teatro de operações" e "teatro da luta". As inúmeras expressões ligadas ao teatro - anfiteatro, cenário, palco, tragédia, atores, platéia, espectadores - permitem a Euclides desenvolver uma idéia central em sua escrita: a inversão de papéis. Decorrem de tal inversão, conforme notou Leopoldo Bernucci, as principais figuras de linguagem e pensamento do livro, como a antítese, o oxímoro e a ironia, que mostram a ilusão e o avesso das coisas e estabelecem correspondências momentâneas entre os objetos, que logo se convertem em ilusões ou paradoxos, a exemplo da visão do céu transformada em inferno ou do deserto que cria a miragem do mar (24).

Inspirada no drama, a inversão de papéis fortalece, com sua poderosa ironia, a semelhança entre os lados opostos, ao revelar o deslocamento e o intercâmbio de lugares entre a civilização e a barbárie. A matança dos prisioneiros é tomada como um "drama sanguinolento da Idade das cavernas", ou um "recuo prodigioso no tempo", em que os soldados e oficiais, supostos representantes do progresso, agiam de forma primitiva:

"Descidas as vertentes, em que se entalava aquela furna enorme, podia representar-se lá dentro, obscuramente, um drama sanguinolento da Idade das cavernas. O cená- 
rio era sugestivo. Os atores, de um e de outro lado, negros, caboclos, brancos e amarelos, traziam, intacta, nas faces, a caracterização indelével e multiforme das raças - e só podiam unificar-se sobre a base comum dos instintos inferiores e maus".

Os heróis irrompem, na narrativa, para dar conta dos poucos momentos em que o conflito adquire "delineamentos épicos", ou contornos grandiosos, pela troca de papéis entre os soldados, depreciados pelo narrador, e os sertanejos, que são valorizados. Um grupo de conselheiristas ataca, de forma tão brava quanto suicida, o possante canhão Whitworth, apelidado de matadeira, que rugia sobre Canudos como um "animal fantástico". Um prisioneiro se estrangula com uma corda e se converte, enrijecido, em uma "velha estátua de titã, soterrada havia quatro séculos e aflorando, denegrida e mutilada, naquela imensa ruinaria de Canudos". Observa Euclides com severa amargura: "Era uma inversão de papéis. Uma antinomia vergonhosa..." (25 ).

A paisagem é vista, em "A Terra", primeira parte de Os Sertões, como cenário trágico, que antecipa de modo simbólico a decapitação dos prisioneiros. A vegetação da caatinga permitiria antever a degola dos sertanejos, que se converte em tragédia inscrita na própria natureza. As cabeçasde-frade, com suas flores intensamente rubras, espalham-se sobre a pedra nua e criam "a imagem singular de cabeças decepadas e sanguinolentas jogadas por ali, a esmo, numa desordem trágica". As palmatórias-do-inferno, "diabolicamente eriçadas de espinhos", evocam a paixão de Cristo, sacrifício exemplar que se liga à paixão e morte dos seguidores do Conselheiro.

Com sua visão teatral da guerra, o narrador transforma o espaço geográfico em cenário de um "emocionante drama" histórico. O sertão de Canudos surge como "monstruoso anfiteatro", cujo isolamento se reforça pelo círculo de montanhas à volta, que evocaria os teatros ao ar livre da Antigüidade e traria a certeza da impunidade para a "multidão criminosa e paga para matar", formada pelas tropas republicanas (26).
Euclides apresentou as batalhas, a que assistiu como repórter, como quadros e cenas vistos de tribunas elevadas ou de camarotes, representados pelos morros ao redor de Canudos. As metáforas teatrais, enlaçadas com imagens pictóricas, convertem as batalhas em espetáculo, em que o narrador retoma o papel do coro da tragédia clássica, comentando os acontecimentos, lamentando as vítimas e acusando os vencedores.

A violenta batalha de 24 de setembro de 1897, que resultou no cerco de Canudos, é narrada, segundo Berthold Zilly, de um modo épico e plástico, com longas descrições de quadros e imagens, e depois como um ato de tragédia, em que as imagens se tornam teatrais e dinâmicas. O discurso teatral aparece com maior freqüência nesses últimos capítulos, à medida que a destruição da comunidade ganha um sentido trágico de hecatombe ou de final apocalíptico.

Contado com intensa dramaticidade, o combate é central no desenrolar da guerra, pois permitiu às forças armadas cercar a cidade e selar a sua derrota, ao privar seus habitantes de água e comida. Observa Euclides: "traçara-se a curva fechada do assédio real, efetivo. A insurreição estava morta”. Munido de binóculos, o narrador acompanha o espetáculo do alto do morro, junto com os oficiais, que formavam uma "platéia enorme para a contemplação do drama", entusiasmada com os avanços das tropas: "Aplaudia-se. Pateava-se. Estrugiam bravos. A cena - real, concreta, iniludível - aparecia-lhes aos olhos como se fora uma ficção estupenda, naquele palco revolto, no resplendor sinistro de uma gambiarra de incêndios".

Os incêndios que se espalhavam pelo casario lembravam os refletores do teatro e as nuvens de fumaça amarelada tomavam o quadro de modo semelhante ao sombreado de um desenho e chegavam, por vezes, a escondê-lo "como o telão descido sobre um ato de tragédia”. O fumo, que cobria o arraial, estendia-se diante dos espectadores e fazia lembrar a base parda, que serve de primeira demão para uma pintura:

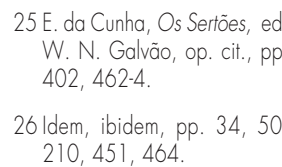

W. N Galvão, op cit pp. $6 \mathrm{ldem}$, ibidem, pp. 34, 50 $210,451,464$ 


\section{Abaixo, \\ bóia na bateria}

do perigo;

na página

seguinte,

sepultura do

capitão Aguiar

27 ldem, ibidem, pp. 451-2.
“As vistas curiosas dos que pelo próprio afastamento não compartiam a peleja, coavam-se naquele cendal de brumas. E quando estas se adunavam impenetráveis, em toda a cercadura de camarotes grosseiros do monstruoso anfiteatro explodiam irreprimíveis clamores de contrariedades e desapontamentos de espectadores frenéticos, agitando os binóculos inúteis, procurando adivinhar o enredo inopinadamente encoberto" (27).

Ausente das reportagens, a degola de centenas de prisioneiros ao final da guerra é referida de forma velada em Os Sertões, ainda que sejam contados alguns casos de decapitação, estripamento ou esfaqueamento de sertanejos. Um jovem prisioneiro, que respondia altivo e indiferente a todas as perguntas com um "Sei não!", pede para morrer de tiro, mas o soldado lhe enfia, sem piedade, a faca na garganta, enquanto este dá um último grito, que sai gargarejante pela boca ensangüentada: "Viva o Bom Jesus!..."

Um outro prisioneiro, levado à tenda do general João da Silva Barbosa, comandante da 1 a Coluna, balbucia algumas frases mal percebidas e tira o chapéu de couro para se sentar. Mas é derrubado a socos por sua insolência e arrastado com uma corda amarrada ao pescoço para o "seio misterioso da caatinga", onde é morto como tantos outros presos com requintes de crueldade:

“Os soldados impunham invariavelmente à vítima um viva à República, que era poucas vezes satisfeito. Era o prólogo invariável de uma cena cruel. Agarravam-na pelos cabelos, dobrando-lhe a cabeça, esgargalandolhe o pescoço; e, francamente exposta a garganta, degolavam-na. Não raro a sofreguidão do assassino repulsava esses preparativos lúgubres. O processo era, então, mais expedito: varavam-na, prestes, a facão.

Um golpe único, entrando pelo baixo ventre. Um destripamento rápido...”.

Tal morte a faca, ou "a frio", era o supremo pavor dos sertanejos, que acreditavam que, por esta forma, não lhes seria salva a alma. Os soldados exploravam a superstição e prometiam, não raro, a esmola de um tiro à custa de revelações, ou exigiam

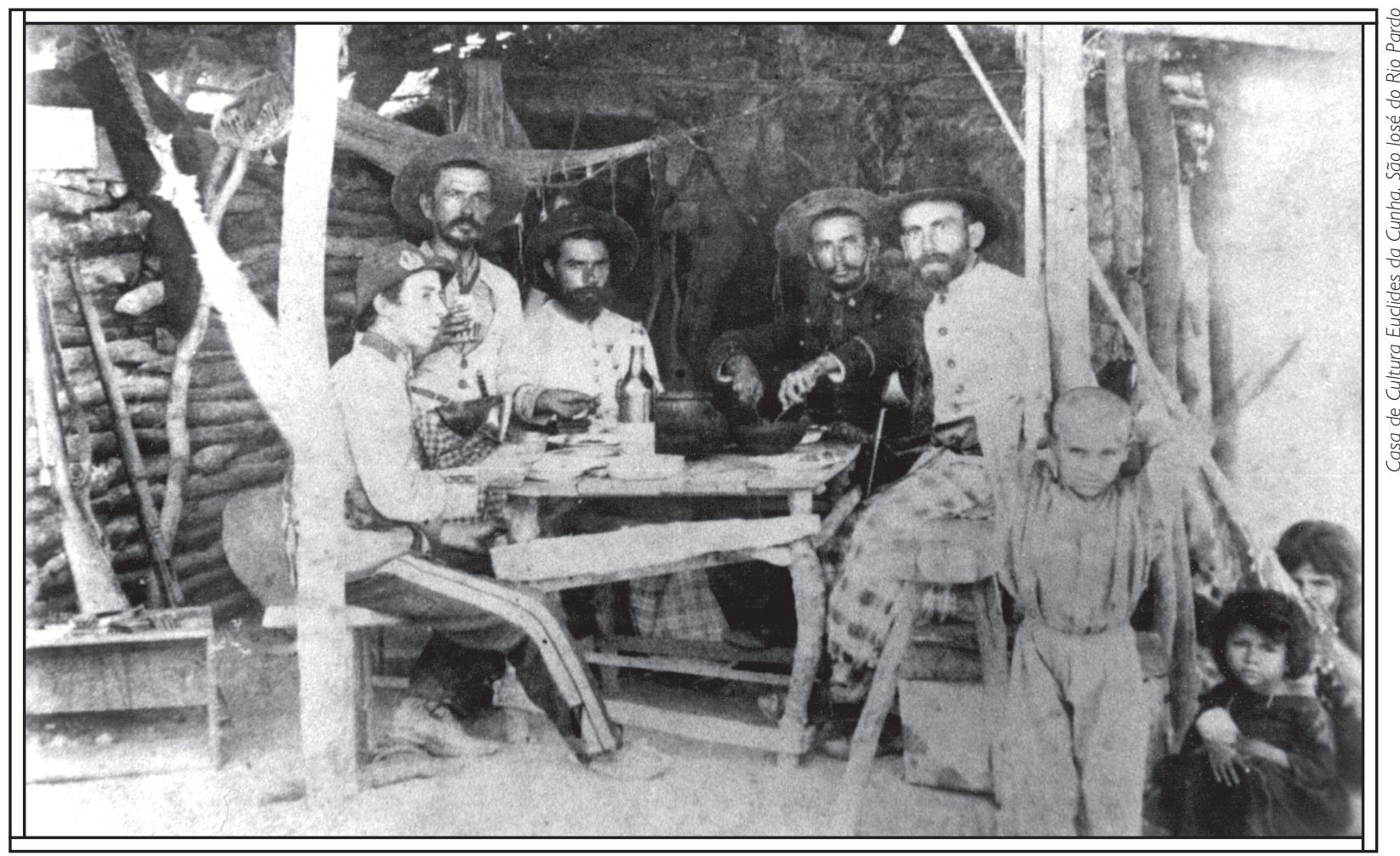


que dessem um viva à República. Conhecendo a sorte que os aguardava caso fossem presos, muitos sertanejos preferiam lutar até à morte. Sentencia o escritor: “Aquilo não era uma campanha, era uma charqueada. Não era a ação severa das leis, era a vingança" (28).

Euclides foi testemunha ocular dos momentos finais da guerra, tendo presenciado cerca de três semanas de luta, de 16 de setembro a 3 de outubro de 1897, quando se retirou de Canudos doente, com acessos de febre, dois dias antes do fim do conflito (29). Não assistiu ao massacre dos prisioneiros, à queda e ao incêndio da cidade, ou à descoberta do cadáver do Conselheiro e de seus manuscritos, fatos ocorridos entre 3 e 6 de outubro, que não mencionou nas reportagens e que iria depois relatar de forma sucinta em seu livro.

O narrador de Os Sertões recua diante de um fato inexprimível e irrepresentável, que ultrapassa os seus quadros de referência pela covardia e violência extremas: a matança dos presos que se haviam rendido. Assim como entrevia, durante as batalhas, o arraial de Canudos através das cortinas de fumaça que se erguiam das ruínas, a chacina dos presos é insinuada, ao invés de ser relatada. Sua narrativa repousa sobre uma estrutura tensa devido ao conflito entre a necessidade de revisitar um evento traumático do passado e a impossibilidade de representar aquilo que desafia ou supera os limites da linguagem (30).

Escreveu na abertura do livro: "Aquela campanha lembra um refluxo para o passado./ E foi, na significação integral da palavra, um crime./ Denunciemo-lo". Assumia a mesma atitude de tribuno público que Émile Zola, uma de suas leituras preferidas, tivera, em 1898, no célebre caso Dreyfus na França. Em “J'Accuse" (“Eu Acuso"), carta aberta ao presidente da República, Zola denunciou a conspiração militar que transformara o capitão Alfred Dreyfus, descendente de judeus, em bode expiatório de um caso de espionagem, que envolvia a venda de segredos militares aos alemães. Condenado em 1894 à prisão perpétua na temida prisão da Ilha do Diabo, na costa da Guiana Francesa,
Casa de Cultura Euclides da Cunha, São José do Rio Pardo

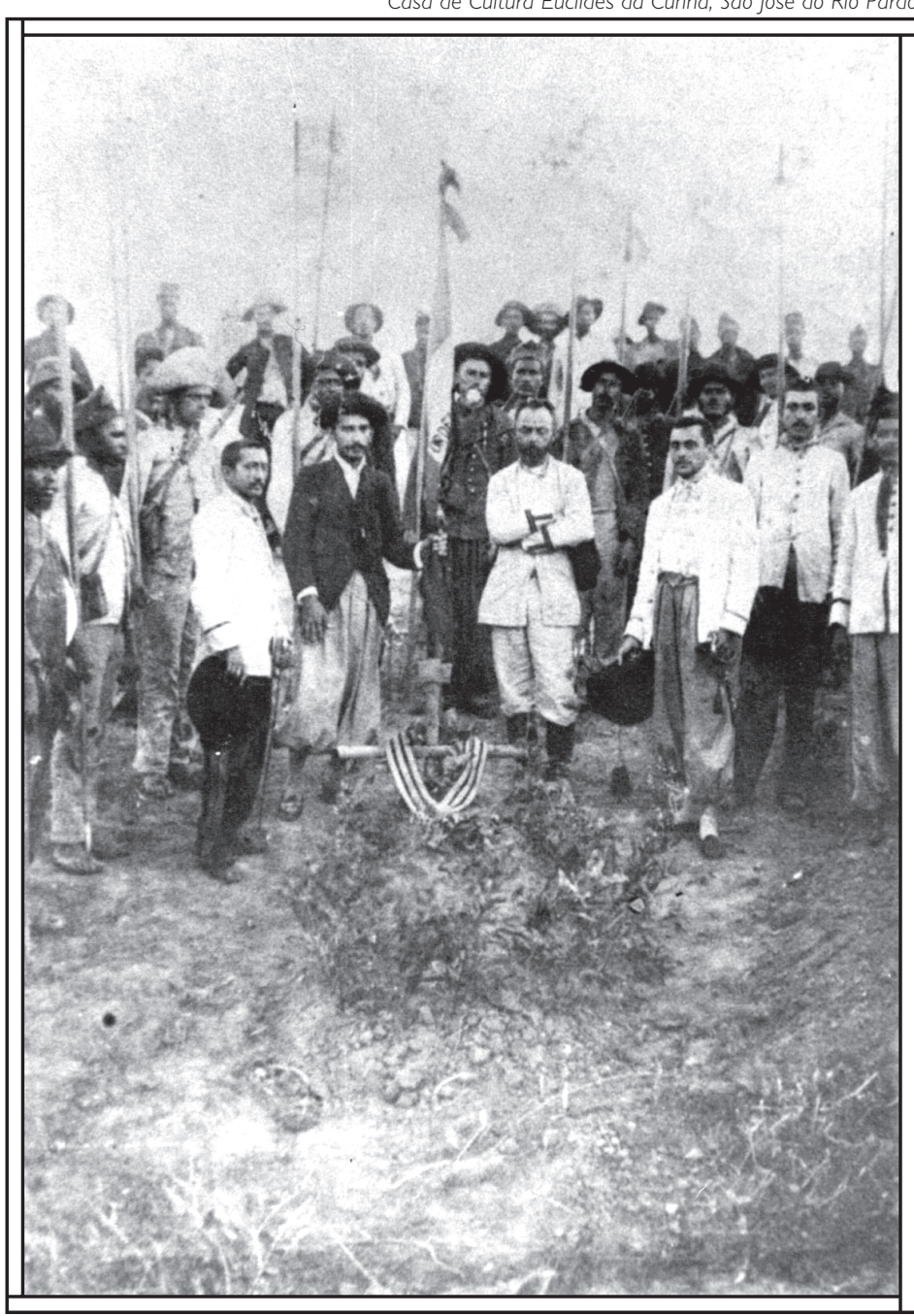

Dreyfus obteve a anistia em 1899 após intensa campanha pública, mas só foi plenamente reabilitado e reintegrado ao Exército sete anos depois, em 1906 (31).

O crime ocorrido em Canudos, pelo qual Euclides acusa as forças armadas, recebe um tratamento simbólico ou figurativo em Os Sertões, como na imagem das cabeçasde-frade espalhadas pela caatinga, que metaforiza a degola e evita a platitude do registro realista ou do testemunho meramente documental. Sua narração suspensiva do massacre resultou de uma opção estética em evitar o apelo ao patético e fugir à representação de fatos cruentos: “E de que modo comentaríamos, com só a fragilidade da palavra humana, o fato singular de não aparecerem mais, desde a manhã de 3 , os prisioneiros válidos colhidos na véspera?".
28 Idem, ibidem, p. 401, 458-9, 463

29 José Calasans, "Euclides da Cunha nos Jornais da Bahia in Cartografia de Canudos, Salvador Secretaria de Cultu ra e Turismo do Estado da Bahia, 1997, pp. 130-1.

30 Sobre a representação de ca tástrofes como o holocausto História como Trauma", in Arthu Nestrovski e Márcio SeligmannSilva (orgs.), Catástrofe e Re presentação: Ensaios, pp. 90 e segs.

31 E. da Cunha, Os Sertões, op. cit., p. 14. Sobre as implicacões políticas e culturais do caso Dreyfus na Terceira Repu blica francesa, cf.: Eugen Weber, France, Fin de Siècle Cambridge Massachusetts, Harvard Univ. Press, 1986 pp. 120-5 cf.: Márcio Seligmann-Silva, "A 
Deixa igualmente de narrar os derradeiros combates e prefere conter sua pena ante a carnificina. Canudos foi, para ele, um "exemplo único em toda a História", por ter resistido até ao esgotamento completo com apenas quatro guerreiros, que lutavam contra cinco mil soldados ferozes. Tal elipse narrativa, que torna a matança subentendida, tem função semelhante à do decoro na tragédia, em que se impedia a visão das cenas violentas, com derramamento de sangue, que eram representadas fora de cena, dentro do palácio real, enquanto os espectadores ouviam os gritos da vítima (32).

O tom sombrio, que adota nos capítulos finais de Os Sertões, expressa a infame inversão de papéis entre soldados e conselheiristas, que transformou a campanha em matadouro: "que entre os deslumbramentos do futuro caia, implacável e revolta; sem altitude, porque a deprime o assunto; brutalmente violenta, porque é um grito de protesto; sombria, porque reflete uma nódoa - esta página sem brilhos..." (33).

Critica e ironiza, em tal página "sem brilhos", a cintilação ilusória das glórias e insígnias militares, manchadas por atos indignos. Faz ainda a paródia do entusiasmado telegrama que o presidente da República, Prudente de Morais, enviou ao ministro da Guerra, marechal Bittencourt, e ao comandante da última expedição, general Artur Oscar, para transmitir suas "congratulações pela terminação dessa campanha excepcional, de modo tão honroso para a República quanto glorioso para o Exército nacional, que, através de tantos sacrifícios, acaba de escrever mais uma página brilhante para a nossa história" (34).

A destruição do povoado, cujos mora-

32 Oliver Taplin, Greek Tragedy in Action, London, Methuen, 1978

33 E. da Cunha, Os Sertões, op. cit., p. 464

34 Aristides A. Milton, A Campanha de Canudos, Rio de Janei ro, Imprensa Nacional, 1902 pp. 132-3.

35 Prudente de Morais, "7/out. 1897" in Jornal do Comércio (Rio dejaneiro), 8/out./1897.

\section{A COMÉDIA REPUBLICANA}

Euclides retomou tal visão teatral e irônica da história no breve relato "A Esfinge", de Contrastes e Confrontos (1907), parte do livro que pretendia escrever sobre a Revolta da Armada. Queria, após o êxito de Os Sertões, dar prosseguimento à revisão da história republicana, mas abandonou tal projeto, ao ser nomeado em 1904 para chefiar a Comissão Brasileira de Reconhecimento do Alto Purus, no Acre. Sua atenção intelectual se voltou então para a Amazônia, sobre a qual redigiu os ensaios reunidos em Contrastes e Confrontos e À Margem da História (1909).

Atuou na Revolta da Armada, entre 1893 e 1894, como tenente a serviço das forças do governo, engajadas no combate aos rebeldes da Marinha, que exigiam a realização de eleições presidenciais. Contou, em "A Esfinge", a visita noturna feita pelo marechal Floriano Peixoto, vice-presidente em exercício da Presidência, às obras da fortificação que erguia, como engenheiro militar, no cais do porto do Rio, para abrigar o canhão que iria bombardear os navios insurgentes. O marechal, que governava o país com mão de ferro, surgia aos seus olhos como esfinge, em cuja face enigmática via inscritos os destinos do país.

O sogrode Euclides, o general Frederico Solon Sampaio Ribeiro, um dos chefes militares da proclamação da República, encontrava-se preso sob a acusação de envolvimento com os revoltosos. Em meio a tantos conflitos, o engenheiro-escritor lia a obra histórica do inglês Thomas Carlyle, The French Revolution (A Revolução Francesa) (1837), em que são criticados os abusos do poder revolucionário. Procurava, nas páginas de Carlyle, encontrar consolo para os descaminhos do novo regime, desvirtuado por guerras civis, e se penitenciar do que chamou de "uso desta espada inútil, deste heroísmo à força e desta engenharia malestreada...".

Contemplando, durante a Revolta da Armada, os navios de guerra imersos à noite na escuridão da baía, Euclides se sentia 
como o figurante de um drama trágico:

“Imaginei-me, então, obscuríssimo comparsa numa dessas tragédias da antigüidade clássica, de um realismo estupendo, com os seus palcos desmedidos, sem telão e sem coberturas, com os seus bastidores de verdadeiras montanhas em que se despenhavam os heróis de Ésquilo, ou o proscênio de um braço de mar, onde uma platéia de cem mil espectadores pudesse contemplar, singrantes, as frotas dos Fenícios".

Nesse drama histórico, os papéis se confundiam e se invertiam com ironia cômica. O governo, suposto representante da legalidade, "belo eufemismo destes tempos sem leis", decretava o estado de sítio e esmagava os rebeldes pela suspensão das leis. A Constituição, por sua vez, era estrangulada pelos "abraços demasiado apertados dos que a adoram": "Representamos desastradamente. Baralhamos os papéis da peça que deriva num jogar de antíteses infelizes, entre senadores armados até aos dentes, brigando como soldados, e militares platônicos bradando pela paz".

A história republicana se encenava como comédia trágica ou era narrada enquanto epopéia sem heróis, em que o estilo elevado se rebaixava pela perspectiva irônica: "Os heróis desmandam-se em bufonerias trágicas. Morrem, alguns, com um cômico terrível nesta epopéia pelo avesso" (36). Recorria à inversão de papéis, idéia já empregada em Os Sertões para tratar do intercâmbio de lugares entre o bárbaro e o civilizado. Tal noção teatral era usada agora em sua variante cômica, o qüiproquó, ou o quid pro quo, troca de papéis entre as coisas ou os personagens, que cria no palco situações burlescas e engraçadas, cuja solução depende de serem desfeitos os equívocos e as confusões.

\section{A TRAGÉDIA DA PIEDADE}

Euclides teve, como o Conselheiro, um fim trágico. Ambos foram construtores itinerantes, um de capelas, igrejas e cemitérios, o outro de pontes, escolas e estradas. Os dois tiveram o destino marcado pelo adultério das esposas, pela luta sangrenta de suas famílias contra seus inimigos e pelas posições que assumiram frente à República, um de feroz oposição, o outro de adesão entusiástica, seguida de crítica mordaz. Ambos tiveram fé, o líder religioso na força redentora da devoção e do ascetismo, o escritor no poder transformador da literatura, da ciência e da filosofia.

Euclides morreu, em 15 de agosto de 1909, no bairro da Piedade, no Rio de Janeiro, em tiroteio com o cadete Dilermando de Assis, amante de sua mulher. Sete anos depois, Dilermando fuzilou, em um cartório no centro do Rio, o aspirante naval Euclides da Cunha Filho, o filho preferido do escritor, que tentava vingar o pai.

A imprensa noticiou a morte do autor de Os Sertões como a "tragédia da Piedade", usando as mesmas imagens teatrais presentes em sua obra. Comparou depois, em 1916, o destino de seu filho ao drama do Hamlet de Shakespeare, obcecado em desforrar o pai assassinado. Ao agir como os heróis antigos ou como os valentões sertanejos, a vida de Euclides se tornou uma ficção trágica.
36 E. da Cunha, "A Esfinge", in Contrastes e Confrontos (1907), São Paulo, Brasília Cultrix, INL, 1975 , p. 124 lrepubl em: Obra Completo 1995 , v. 1, pp. 200, 2031 